Original Article

\title{
PROPERTIES OF HONEY AND POLLEN SAMPLES OBTAINED FROM DIFFERENT RHODODENDRON SPECIES COLLECTED FROM BLACK SEA REGION OF TURKEY
}

\author{
Sezai Alkan ${ }^{1 *}$ \\ Mert Akgün ${ }^{1}$ \\ Ömer Ertürk² \\ Melek Çol Ayvaz ${ }^{1}$ \\ Ceren Başkan ${ }^{3}$ \\ 'Department of Animal Science, Faculty of Agriculture, Ordu University, Ordu, \\ Turkey \\ 2Department of Molecular Biology and Genetics, Faculty of Science and Arts, Ordu \\ University, Ordu, Turkey \\ 3Sabuncuoğlu Şerefeddin Health Services Vocational School, Amasya University, \\ Amasya, Turkey \\ *corresponding author: sezaialkan61@gmail.com \\ Received: 04 March 2020; accepted: 26 July 2020
}

\section{Abstract}

Physicochemical properties as well as antioxidant and antimicrobial capabilities of Rhododendron honey and pollen produced in Turkey were determined. Monofloral honey samples from three different $R$ hododendron species $(R$. ponticum $L$., $R$. Iuteum $L$., and $R$. caucasicum $\mathrm{L}$.) were collected from the mountains of the Eastern Black Sea Region of Turkey. The experimental results revealed that each crude extract of honey and pollen exhibited significant antibacterial and antifungal capacity in the bacteria and fungus. The pollen samples and SEM images have been analysed and recorded. The total phenolic contents and antioxidative activities of the samples were investigated based on DPPH free radical scavenging activities and ferric reducing antioxidative power potentials, and higher phenolic content and antioxidant activities were observed for pollen samples with respect to honey. Furthermore, the potential to inhibit Acetyl- and Butrylcholinesterase activity and lipid peroxidation were evaluated. The potential to inhibit DNA damage were also studied, and $R$. ponticum honey was observed to influence most positively damaged DNA.

Keywords: anti-cholinesterase, antioxidant and antimicrobial activity, DNA damage, honey quality, phenolic content, Rhododendron

\section{INTRODUCTION}

The rhododendrons of the Ericaceae family are widespread in the northern hemisphere and constitute a large part of vascular plants. There аге eight different subgenera and more than 800 species of this genus. However, only five species of Rhododendron are available in Turkey, the most abundant being Rhododendron ponticum and Rhododendron flavum. Although the toxic properties of rhododendrons are well known and some species are even poisonous, these plants have been used for treatment since ancient times due to their positive effects on inflammatory conditions, pain, gastro-intestinal disorders, common cold, asthma, skin diseases, etc. The toxicity of rhododendrons has been attributed to grayanotoxins, which are present in leaves, flowers and nectar (Popescu \& Kopp, 2013; Silici et al., 2014).

Honey has been reported to have an inhibitory effect on around sixty species of bacteria including aerobes and anaerobes, gram-positives and gram-negatives (Manyi-Loh, Clarke, \& Ndip, 2011). Insufficient knowledge of the antimicrobial agents in honey and theirinfluence on bactericidal efficiency hinder overall applicability of natural honey. Researchers have attempted 
to resolve the mechanism of action of honey's antimicrobial effect and appraised the additition of honey components to bactericidal activity against pathogenic bacteria.

Besides toxic diterpenes, Rhododendron species also contain flavonoids, simple phenols and phenolic acids, triterpenoids, tannins and essential oils. The leaves, flowers, pollen and nectar of many Rhododendron species contain toxic diterpenoid, so Rhododendron honey $(\mathrm{RH})$ is known as "mad honey" or "toxic honey". Owing to its content and mysterious features, $\mathrm{RH}$ is produced by beekeepers and sold at relatively high prices as a component for many drugs and as an alternative medicine for its beneficial effects on many health disorders in Turkey's Black Sea Region (Silici, Sagdic, \& Ekici, 2010; Silici et al., 2014). Popescu \& Kopp (2013) examined the pharmacological and biological activities of various plant parts of such types as Rhododendron arboreum Sm., Rhododendron ferrugineum L., Rhododendron molle (Blume) G. Don., Rhododendron simsii Planch and Rhododendron tomentosum Harmaja. Tasdemir et al. (2005), Alan et al. (2010) and Usta et al. (2012) reported on anti-inflammatory and antiprotozoal activities and Acethylcholinestherase inhibition of leaves and stems of Rhododendron ponticumL. and anti-bacterial and anti- protozoal activities as well as Acethylcholinestherase inhibition of Rhododendron luteum sweet leaves from Turkey. However, there is no such finding for Rhododendron caucasicum L. Kurtoğlu et al. investigated honey from $R$. ponticum (Kurtoglu, Yavuz, \& Evrendilek, 2014). On the other hand, most studies about Rhododendron honey do not state clearly which species of Rhododendron was used (Silici, Sagdic, \& Ekici, 2010; Silici et al., 2014), and furthermore there are even fewer about pollen than those about honey. To make up for this lack of literature, in this study, the honey and pollen samples obtained from $R$. ponticum $\mathrm{L}$., $R$. luteum $\mathrm{L}$., and $R$. caucasicum $\mathrm{L}$. were investigated.

The aim of this research is to investigate Rhododendron honey and pollen samples for such physicochemical properties as acidity, moisture, sucrose and hydroxymethyl furfural (HMF) contents and electrical conductivity. SEM images of the samples were recorded. Total phenolic content, antioxidative and antimicrobial activities, potential inhibition of Acetyl- and Butrylcholinesterase activity and lipid peroxidation, potential inhibition of DNA damage and HPLC phenolic analysis were also studied for all samples.

\section{MATERIAL AND METHODS}

\section{Collection of honey and pollen samples}

Pollen and honey materials of Rhododendron ponticum L. subsp. ponticum, Rhododendron luteum L, and Rhododendron caucasicum Pallas L. were collected from the mountains of Turkey's Eastern Black Sea Region when the flora was abundant. The of these species were identified according to Flora of Turkey (Stevens, 1978).

For each Rhododendron species, the honey and pollen samples were collected from three separate beehives. The hives for $R$. luteum honey and pollen were located in the Korgan-Ordu province, for $R$. ponticum honey and pollen in the Yoroz-Ordu province and for $R$. caucasicum honey and pollen in the Anzer Highland-Rize province. The honeys from individual hives were then combined to form the test honey samples. In order to collect raw pollen, pollen traps were installed at the entrance of each hive. Pollen samples collected from three hives in each area were combined afterwards.

\section{Preparation of honey and pollen extracts}

Honey samples (50 g) and raw pollen samples were chopped into small pieces (50 g) and then extracted with $250 \mathrm{~mL}$ of $95 \%$ ethanol through continuously stirring with a digital orbital shaker (SHO-2D, DAlHAN Scientific Co., Ltd., S. air-conditioning booth, Grotech brand, GR8 model, Unitroniks) at $180 \mathrm{rpm}$ and $24^{\circ} \mathrm{C}$ with 18/6 light/dark period (single extraction). The suspension was filtrated, and the supernatant was separated after centrifugation at 10,000 rpm for $15 \mathrm{~min}$. The ethanolic solution was then concentrated in a rotary evaporator under reduced pressure at $40^{\circ} \mathrm{C}$ to obtain the crude 
extract in paste form and kept in a dry and dark place at $4^{\circ} \mathrm{C}$ until use (Chang et al., 2002).

Pollen samples were prepared according to the method described by Louveaux, Maurizio, \& Varwohl (1978). $10 \mathrm{~g}$ of pollen sample was dissolved in $20 \mathrm{~mL}$ of distilled water, divided into two centrifuge tubes of $15 \mathrm{~mL}$, and centrifuged for approximately $10 \mathrm{~min}$ at 4000 rpm. The same procedure was repeated after distilled water was added to the sediment. A glycerine - water mixture (1:1) $5 \mathrm{~mL}$ was added to the sediment and was left to rest for $30 \mathrm{~min}$ prior to centrifugation. The sediment was then removed with the aid of a stylet, embedded in glycerine jelley and deposited on a microscopic slide sealed with paraffin wax. Pollen analysis was performed under light microscope in order to classify the samples as monofloral or not.

Scanning electron microscopy (SEM) images were recorded using Hitachi model SU1510. For SEM evaluation, properly dried pollen of each cultivar for electron microscopy shot stubs were secured with double-sided carbon tape glued on and fixed samples were coated with $15 \mathrm{~nm}$ gold-palladium (SEM coating system, sputter). SEM imaging was conducted at 5-15 $\mathrm{kV}$ voltage at $1000 \mathrm{x}$.

\section{Physicochemical analysis and analysis of phenolic compounds by HPLC}

The AOAC method was used for determining such physicochemical features as moisture, acidity and sucrose content (AOAC, 1990). Hydroxymethyl furfural (HMF) was determined after the addition of sodium bisulphate to the clarified honey samples. Absorbance was measured at 284 and $336 \mathrm{~nm}$ using a UV/ Vis spectrophotometer. Diastase activity was determined using a buffered solution of soluble starch and honey incubated in a thermostatic bath at $40^{\circ} \mathrm{C}$. Afterwards, $1 \mathrm{~mL}$ aliquot of this mixture was removed at 5 min intervals and the absorption of the sample was followed at 660 $\mathrm{nm}$ (Official Method 958.09) (AOAC, 1990). The diastase value was calculated using the time taken for the absorbance to reach 0.235, and the results were expressed in Gothe degrees as the amount $(\mathrm{mL})$ of $1 \%$ starch hydrolyzed by an enzyme in $1 \mathrm{~g}$ of honey in $1 \mathrm{~h}$. Single measurements were performed on homogenized honey and pollen samples for physicochemical analyzes.

The following nineteen standards of phenolic compounds were analyzed using HPLC (Elite LaChrom Hitachi, Japan): gallic acid, protocatechuic acid, $p$-OH benzoic acid, catechin, caffeic acid, syringic acid, epicatechin, $p$-coumaric acid, ferulic acid, rutin, myricetin, resveratrol, daidzein, luteolin, $t$-cinnamic acid, hesperetin, chyrisin, pinocembrin, phenylethyl caffeate. The samples were injected into the HPLC system with a reverse phase C18 column (150 $\mathrm{mm} \times 4.6 \mathrm{~mm}, 5 \mu \mathrm{m}$; Fortis). The mobile phase was a mixture of solvent $A(2 \% \mathrm{AcOH}$ in water) and solvent $B(70: 30$, acetonitrile/water) which was sonicated before stirring and continuousIy degassed by the built-in HPLC system. The injection volume was $20 \mu \mathrm{L}$ and the column was kept at $30^{\circ} \mathrm{C}$. The flow rate kept constant at 1 $\mathrm{mL}$ min $^{-1}$ using gradient programming, started the flow of mobile phase as B $(5 \%)$ to three minutes, gradually increasing (up-to 15, 20, 25, 40 and $80 \%$ at $8,10,18,25$ and 35 minutes respectively) and decreasing to $5 \%$ at 40 minutes and left for 10 minutes to equilibrate in the column. The phenolic profile was determined according to Can \& Baltas (2016).

\section{Bacterial and fungal strains and growth conditions}

The antimicrobial activity of the samples were studied against Enterococcus feacalis (ATCC ${ }^{\circledR}$ 29121), Bacillus cereus (ATCC ${ }^{\circledR}$ 11778), Escherichia coli (ATCC ${ }^{\circledR 25922), \quad K l e b s i e l l a ~}$ pneumoniae (ATCC ${ }^{\oplus 13883), ~ L i s t e r i a ~ m o n o c y-~}$ togenes (ATCC ${ }^{\oplus 7677), ~ S t a p h y l o c o c c u s ~ a u r e u s ~}$ (ATCC ${ }^{\circledR}$ 6538), Citrobacter freundii(ATCC $\left.{ }^{\circledR} 43864\right)$, Candida albicans (ATCC $\left.{ }^{\circledR} 10231\right)$, and Saccharomyces cerevisiae ATCC $^{\circledR}$ 9763). Mueller Hinton Agar (MHA, Merck) or Mueller Hinton Broth (MHB, Merck) and Sabouraud Dextrose Broth (SDB, Difco) or Sabouraud Dextrose Agar (SDA, Oxoid) were used for the growth of bacterial and fungal cells, respectively. 


\section{Antibacterial and antifungal assay and minimum inhibition concentration (MIC)}

Antibacterial and antifungal activities were measured using methods of disc diffusion on agar plates (Ertürk, 2006). All bacterial strains were grown in Mueller Hinton Broth medium (Merck) for $24 \mathrm{~h}$ at $37^{\circ} \mathrm{C}$, and fungal strains were grown in Sabouraud Dextrose Broth (Difco) at $30^{\circ} \mathrm{C}$ for $48 \mathrm{~h}$. Bacterial suspension with a turbidity of 0.5 McFarland and fungal suspension with a turbidity of $1.0 \mathrm{McF}$ carland standards were prepared. Thus, the concentration was adjusted to $10^{8}$ cells $/ \mathrm{mL}$ for bacterial suspensions and to $3 \times 108$ cells/mL for fungal suspensions. Sterile paper discs (6 mm in diameter) were then placed on the agar for $30 \mu \mathrm{L}$ of each sample $(40 \mathrm{mg} / \mathrm{mL})$ to be loaded. 100 units of nystatin for fungus and Ampicillin and Cephazolin for bacteria, all obtained from a local pharmacy, were used as positive controls, and alcohol was used as a negative control. Inhibition zones were determined after incubation at $27^{\circ} \mathrm{C}$ for $48 \mathrm{~h}$. Inhibition zones of different organisms by different samples were measured with the help of a digital caliper to estimate the potency of antibacterial and antifungal substance and then tabulated. All measurements were performed on triplicate samples.

The MIC values represent the lowest honey and pollen extract concentration that completely inhibits the growth of microorganisms and were determined through the micro-well dilution method (Ertürk, 2006). All the extracts were dissolved in $70 \%$ ethanol and water, and then the dilution series were prepared in a 96-well plate (Corning). A Tris buffer (Amresco 0826-500G) mixture (1:4) was mixed at $30^{\circ} \mathrm{C}$ with an equal amount of broth solution (Sabouraud Dextrose Agar (Oxoid) for fungi and Mueller Hinton broth (Merck) for bacteria. Each honey and pollen sample was tested at concentrations of $6000,3000,1500,750,375$, 187.5, 93.75 and $46.75 \mu \mathrm{g} / \mathrm{mL}$. Inoculants were obtained from an overnight broth culture of the test organism. The broth culture was incubated at $35^{\circ} \mathrm{C}$ until it achieved the turbidity of the 0.5 McFarland standards (usually 24-48 h hours). The inoculum of each bacterium was prepared, and the suspensions were adjusted to $10^{8} \mathrm{CFU} /$ $\mathrm{mL}$ for bacteria and $10^{7} \mathrm{CFU} / \mathrm{mL}$ for fungi. After solubilization, each well was inoculated with 5 $\mu \mathrm{L}$ of freshly prepared bacterial suspension of $1 \times 10^{8}$ bacteria, $1 \times 10^{7}$ fungus $/ \mathrm{mL}$, and incubated at $37^{\circ} \mathrm{C}$ for 24 hours. Amoxicillin and Cefazolin was used as positive control for bacteria and nystatin was used for fungi at 1500, 750, 375, 187.5, $93.7546 .75,23.375$ and $11.687 \mu \mathrm{g} / \mathrm{mL}$ concentrations, while $70 \%$ ethanol was used as negative control. Then, $30 \mu \mathrm{L}$ of 3-(4, 5-dimethyl-thiazol-2-yl)-2.5-diphenyl-tetrazolium bromide (MTT) at a final concentration of 0.5 $\mathrm{mg} / \mathrm{mL}$ freshly prepared in water was added to each well and incubated for 30 min. The change to red colour indicated that the bacteria were biologically active. The MIC was taken to the well, where no change of colour in MTT was observed and the MIC values were given as mean of triplicate analysis.

\section{Antioxidant activity studies}

All antioxidant activity studies were performed on triplicate measurements.

Total phenolic content

Total phenolic content of the honey and pollen samples were determined by Folin-Ciocalteu assay (Singleton \& Rossi, 1965) and expressed as gallic acid equivalent (GAE).

DPPH free radical scavenging activities

DPPH free radical scavenging activities of the extracts were tested by following the bleaching of the purple-coloured methanol solution of 2,2-diphenyl-1-picrylhydrazyl (DPPH) at $517 \mathrm{~nm}$ after the addition of the extracts at different concentrations to DPPH solution prepared in methanol. Scavenging activity value obtained for each concentration was calculated using the following equation:

Scavenging Activity $(\%)=\left(A_{\text {blank }}-A_{\text {sample }}\right) / A_{\text {blank }} \times 100$ where $A$ is the absorbance recorded at $517 \mathrm{~nm}$. $\mathrm{SC}_{50}$ values (extract concentrations providing $50 \%$ inhibition) were also calculated using the activity graph versus concentration values (Sánchez-Moreno, Larrauri, \& Saura-Calixto, 1999).

Ferric-reducing/antioxidant power (FRAP)

The FRAP assay was performed following the 
method based on the principle of reducing the Fe (III)-TPTZ complex in the presence of antioxidants to form blue Fe (II)-TPTZ complex and measurement of maximum absorbance at 595 nm (Oyaizu, 1986). FRAP values for honey and pollen samples were expressed as Trolox equivalents (mM Trolox/g honey).

Acetylcholinesterase (AChE) and butrylcholinesterase (BuChE) inhibition potentials

AChE and BuChE inhibitory activities were measured with the Ellman et al. method (Ellman et al., 1961). Electric eel AChE and equine serum BuChE were used as enzymes, while acetylthiocholine iodide and butyrylthiocholine chloride were used as substrates. The percentage of AChE/BuChE inhibition was determined by comparison of the samples' reaction rates relative to the blank (methanol as extraction solvent in phosphate buffer $\mathrm{pH} 8$ ) using the following equation:

Percent inhibition $=\left(A_{\text {Blank }}-A_{\text {Sample }}\right) / A_{\text {Blank }} \times 100$ where $A$ is the absorbance recorded at $412 \mathrm{~nm}$. Galantamine, alkaloid-type anticholinesterase, was used as reference (Şenol et al., 2010).

Lipid peroxidation inhibition potentials

Inhibition potentials of the extracts on 2,2'-azobis-(2-amidinopropane)-dihydrochloride (ABAP)induced lipid peroxidation were also investigated. For this purpose, linoleic acid solutions were treated with $0.1 \mathrm{mg} / \mathrm{mL}$ of samples in the presence of ABAP and the absorbance change at $234 \mathrm{~nm}$ with time was monitored (Palacios et al., 2011). Lipid peroxidation inhibition potential was expressed as percentage taking into account the change between absorbance values at the beginning and at the end of the period.
Effect of honey and pollen samples on hydroxyl radical-mediated DNA damage

To explore how pollen extracts benefited hydroxyl radical-mediated DNA damage, plasmid DNA pUC18 (Thermo Scientific) was used. Pollen extracts (concentration range from 6.25 to $50 \mathrm{mg} / \mathrm{mL}$ ) were dissolved in tetrahydrofuran (THF, final concentration \% 0.1), and honey extracts (concentration range from 3.125 to 50 $\mathrm{mg} / \mathrm{mL}$ ) were dissolved in dimethyl sulfoxide (DMSO, final concentration \% 0.1). $20 \mu \mathrm{L}$ of reaction mixture was prepared containing 0.25 $\mu \mathrm{g} / \mu \mathrm{L}$ plasmid DNA pUC18, $1 \mu \mathrm{L} 3 \% \mathrm{H}_{2} \mathrm{O}_{2}$ and extracts of pollen and honey in Tris-EDTA (TE) buffer. $\mathrm{H}_{2} \mathrm{O}_{2}$ and $0.1 \%$ tetrahydrofuran treated plasmid DNÂs were used as control groups. The prepared mixtures for each pollen and honey extract were incubated at $37^{\circ} \mathrm{C}$ for $24 \mathrm{~h}$. Then, $2 \mu \mathrm{L}$ of loading dye (bromophenol blue $(0.025 \%)$ and sucrose (4\%) in $\mathrm{H}_{2} \mathrm{O}$ ) was added to the mixture (10 $\mu$ total volume) and the obtained mixtures were loaded on to the $1 \%$ agarose gel. Electrophoresis process was performed for 90 min at $80 \mathrm{~V}$ in TBE buffer (Trisma base, boric acid, EDTA) running buffer ( $\mathrm{pH} 8)$. The gel was imaged under UV light (Akbaş et al., 2013).

\section{RESULTS}

Physiochemical properties of honey samples In order to characterize some of the key features of the honey samples, the parameters moisture, $\mathrm{pH}$, proline content and electrical conductivity were evaluated (Tab. 1) and compared with the limits set by the Turkish Food Codex where applicable (Turkish Food Codex, 2005).

The results of the pollen analysis confirmed that all the Rhododendron honey samples

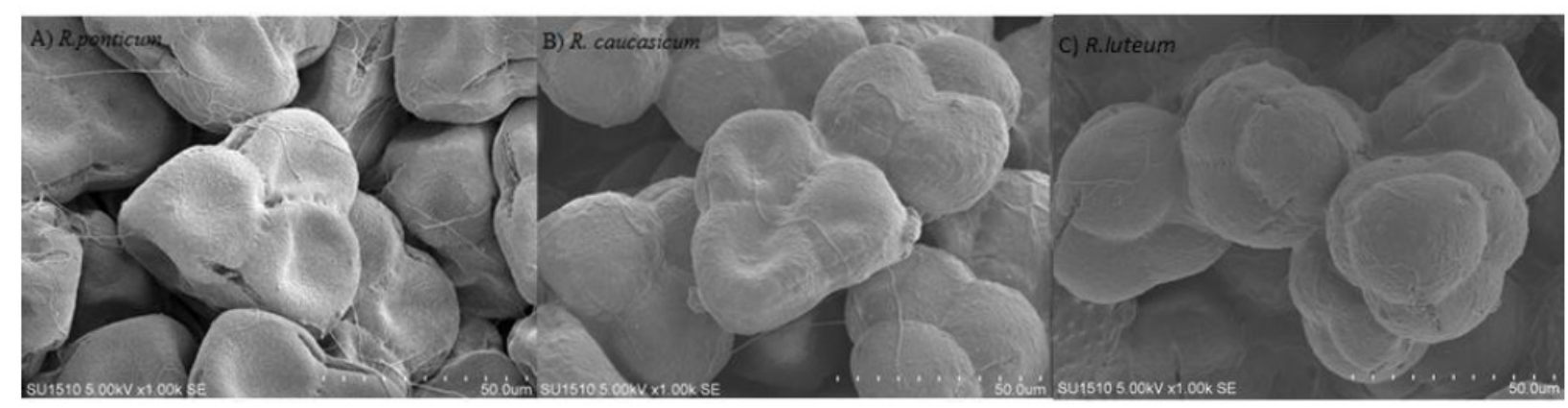

Fig. 1. SEM images of pollen samples obtained from A) $R$. ponticum, B) $R$. caucasicum, and C) $R$. luteum. 
Table 1.

Biochemical content and physicochemical parameters of honey samples

\begin{tabular}{|c|c|c|c|c|c|c|}
\hline & Samples & $\begin{array}{l}R \text {. luteum } \\
\text { honey }\end{array}$ & $\begin{array}{l}R . \text { ponticum } \\
\text { honey }\end{array}$ & $\begin{array}{c}\text { R. caucasicum } \\
\text { honey }\end{array}$ & & \\
\hline No & Analysis & Result & Result & Result & Limits & Method \\
\hline 1 & Fructose $(\mathrm{g} / 100 \mathrm{~g})$ & 35.40 & 38.80 & 38.80 & - & IHC, 2009 \\
\hline 2 & Glucose (g/100g) & 30.20 & 27.30 & 28.30 & - & $\mathrm{IHC}, 2009$ \\
\hline 3 & $\begin{array}{l}\text { Fructose + Glucose } \\
(\mathrm{g} / 100 \mathrm{~g})\end{array}$ & 65.60 & 66.10 & 67.10 & $\begin{array}{l}\text { Minimum } \\
\quad 60\end{array}$ & \\
\hline 4 & Fructose / Glucose & 1.17 & 1.42 & 1.37 & $0.9-1.45$ & \\
\hline 5 & Sucrose (g/100g) & 1.70 & 3.40 & 4.30 & Maximum 5 & IHC,2009 \\
\hline 6 & Maltose (g/100و) & 1.70 & 1.80 & 0.80 & - & IHC,2009 \\
\hline 7 & Proline (mg/kg) & 550.9 & 248.8 & 923.0 & $\begin{array}{l}\text { Minimum } \\
300\end{array}$ & TS 13357 \\
\hline 8 & Number of diastases & 10 & 8.0 & 15.5 & Minimum 8 & IHC,2009 \\
\hline 9 & Moisture (g/100g) & 21.61 & 22.35 & 22.31 & $\begin{array}{l}\text { Maximum } \\
20\end{array}$ & \\
\hline 10 & Brix (g/100g) & 76.81 & 76.09 & 76.13 & - & \\
\hline 11 & $\mathrm{pH}$ & 4.0 & 3.8 & 4.3 & - & \\
\hline 12 & $\begin{array}{l}\text { Electrical Conductivity } \\
\text { (mS/cm) }\end{array}$ & 0.712 & 0.304 & 1.20 & $\begin{array}{l}\text { Maximum } \\
0.8\end{array}$ & \\
\hline 13 & Free Acidity (meq/kg) & 24 & 15 & 24.0 & $\begin{array}{l}\text { Maximum } \\
50\end{array}$ & \\
\hline 14 & HMF (mg/kg) & 0.60 & 0.50 & 0.90 & $\begin{array}{l}\text { Maximum } \\
\quad 40 \\
\end{array}$ & \\
\hline
\end{tabular}

Table 2

The amount of phenolic compounds ( $\mathrm{mg} / \mathrm{g}$ sample) in honey and pollen samples

\begin{tabular}{ccccccc}
\hline Standards & $\begin{array}{c}\text { R. luteum } \\
\text { honey }\end{array}$ & $\begin{array}{c}\text { R. ponticum } \\
\text { honey }\end{array}$ & $\begin{array}{c}\text { R. caucasicum } \\
\text { honey }\end{array}$ & $\begin{array}{c}\text { R. luteum } \\
\text { pollen }\end{array}$ & $\begin{array}{c}\text { R. ponticum } \\
\text { pollen }\end{array}$ & $\begin{array}{c}R . \text { caucasicum } \\
\text { pollen }\end{array}$ \\
\hline Gallic acid & N.D. & N.D. & N.D. & N.D. & N.D. & N.D. \\
Protocateuic acid & N.D. & N.D. & N.D. & N.D. & N.D. & N.D. \\
p-OH Benzoic acid & N.D. & N.D. & N.D. & N.D. & N.D. & N.D. \\
Catechin & 3.76 & N.D. & N.D. & N.D. & N.D. & N.D. \\
Caffeic acid & N.D. & 6.33 & N.D. & N.D. & N.D. & N.D. \\
Syringic acid & N.D. & N.D. & N.D. & N.D. & N.D. & 21.88 \\
Epicatechin & N.D. & N.D. & N.D. & N.D. & N.D. & N.D. \\
p-Coumaric acid & 2.30 & 3.93 & 3.31 & N.D. & N.D. & N.D. \\
Ferulic acid & N.D. & 6.07 & 8.26 & N.D. & 38.19 & N.D. \\
Rutin & N.D. & N.D. & 40.47 & N.D. & N.D. & N.D. \\
Myerecetin & N.D. & N.D. & N.D. & 506.96 & 497.08 & 624.27 \\
Resveratrol & N.D. & N.D. & N.D. & N.D. & N.D. & N.D. \\
Daidzein & N.D. & N.D. & N.D. & N.D. & N.D. & N.D. \\
Luteolin & N.D. & N.D. & N.D. & 16.91 & 207.61 & N.D. \\
t-Cinnamic acid & 0.57 & 0.86 & 1.08 & 14.59 & 63.93 & 34.89 \\
Hesperetin & N.D. & N.D. & N.D. & N.D. & N.D. & 39.83 \\
Chyrisin & 16.81 & 27.44 & 20.16 & N.D. & N.D. & 112.89 \\
Pinocembrin & 2.31 & 4.11 & 2.71 & N.D. & N.D. & 43.90 \\
Phenylethyl caffeate & 3.70 & 4.84 & 2.34 & N.D. & N.D. & 63.17 \\
\hline
\end{tabular}

N.D.: Not determined 
Table 3.

Zones of inhibition (mm) showing the antimicrobial activity of honey and pollen samples

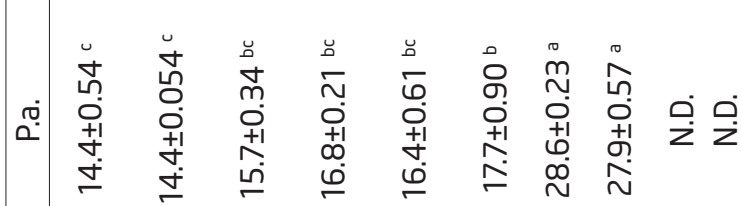

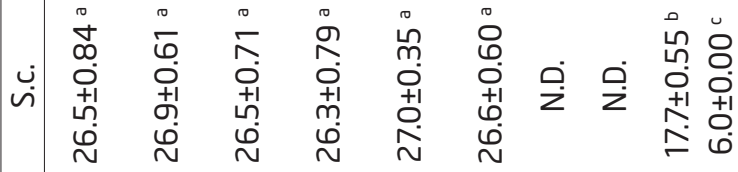

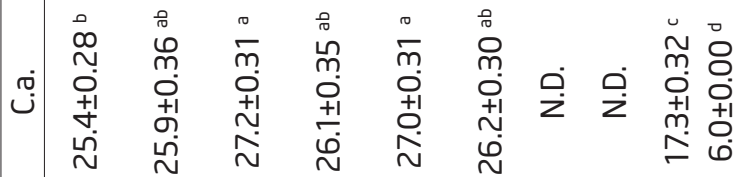

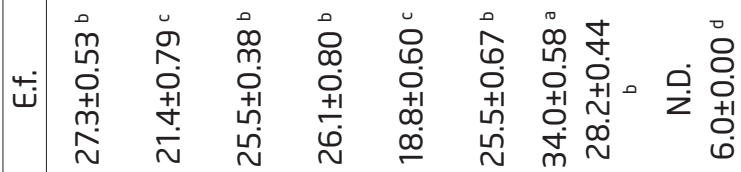

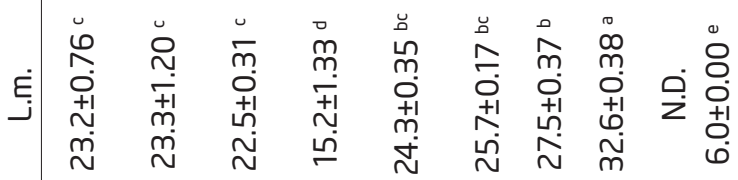

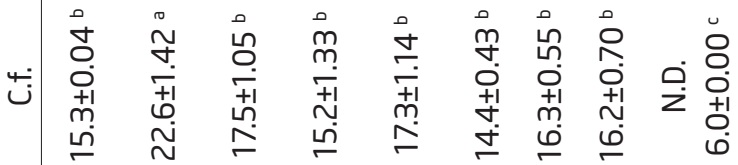

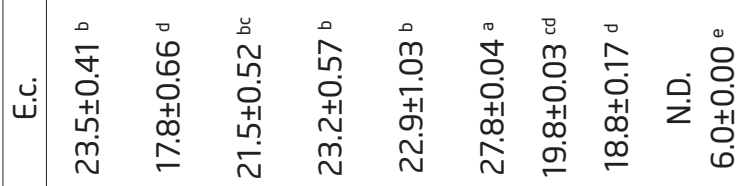

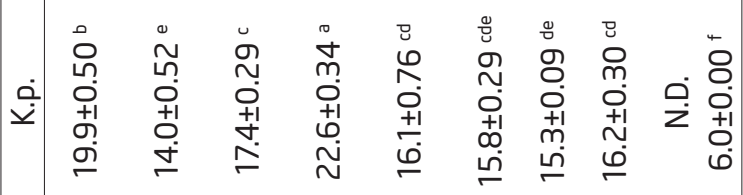

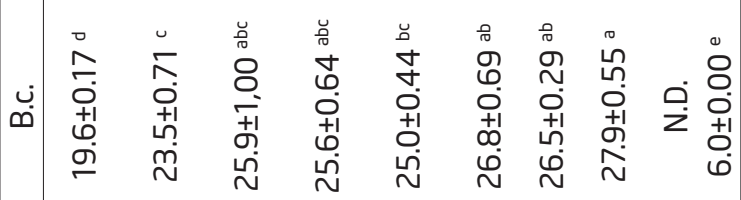

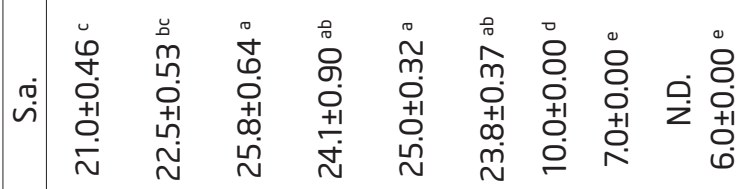

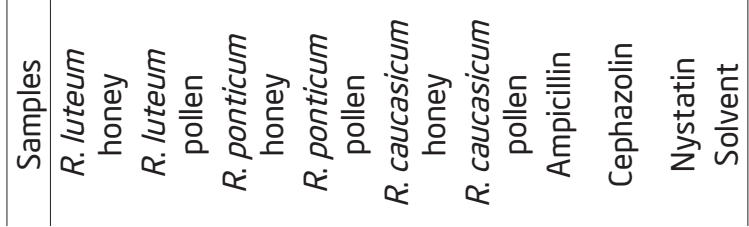

a,b,c,d,e Means in column, with different letters differ significantly at $P<0.01$.

N.D.: Not determined.

Microorganisms: S.a., Staphylococcus aureus ATCC ${ }^{\oplus} 6538$ Gram (+); B.c., Bacillus cereus ATCC ${ }^{\oplus} 11778$ Gram (+); K.p., Klebsiella pneumoniae ATCC ${ }^{\circledR 1} 13883$ Gram (-); E.C., Escherichia coli ATCC 25922 Gram (-); C.f., Citrobacter freundii ATCC ${ }^{\oplus} 43864$ Gram (-); L.m., Listeria monocytogenes ATCC ${ }^{\oplus} 7677$ Gram (+); E.f., Enterococcus feacalis ATCC ${ }^{\oplus} 29121$ Gram (+); C.a., Candida albicans ATCC ${ }^{\oplus} 10231 ;$ S.C., Saccharomyces cerevisiae ATCC ${ }^{\circledR}$ 9763; P.a., Pseudomonas aeruginosa NRRL B-2679Gram (-). 
Table 4.

Minimum inhibition concentrations (MIC) expressed as $\mu \mathrm{g} / \mathrm{mL}$ of honey and pollen samples to inhibit $100 \%$ of the microbial growth in vitro

\begin{tabular}{|c|c|c|c|c|c|c|c|c|c|c|}
\hline Samples & S.a. & B.c. & K.p. & E.c. & C.f. & L.m. & E.f. & C.a. & S.c. & P.a. \\
\hline $\begin{array}{l}\text { R. Iuteum } \\
\text { honey }\end{array}$ & $750 \leq$ & $375 \leq$ & $750 \leq$ & $375 \leq$ & $750 \leq$ & $375 \leq$ & $750 \leq$ & $375 \leq$ & $750 \leq$ & $1500 \leq$ \\
\hline $\begin{array}{l}\text { R. Iuteum } \\
\text { pollen }\end{array}$ & $375 \leq$ & $375 \leq$ & $375 \leq$ & $375 \leq$ & $750 \leq$ & $375 \leq$ & $750 \leq$ & $187.5 \leq$ & $187.5 \leq$ & $1500 \leq$ \\
\hline $\begin{array}{l}R \text { ponticum } \\
\text { honey }\end{array}$ & $375 \leq$ & $375 \leq$ & $750 \leq$ & $375 \leq$ & $375 \leq$ & $375 \leq$ & $750 \leq$ & $187.5 \leq$ & $187.5 \leq$ & $1500 \leq$ \\
\hline $\begin{array}{l}R \text { ponticum } \\
\text { pollen }\end{array}$ & $375 \leq$ & $375 \leq$ & $750 \leq$ & $375 \leq$ & $375 \leq$ & $375 \leq$ & $750 \leq$ & $187.5 \leq$ & $375 \leq$ & $750 \leq$ \\
\hline $\begin{array}{l}\text { R. caucasicum } \\
\text { honey }\end{array}$ & $375 \leq$ & $375 \leq$ & $375 \leq$ & $375 \leq$ & $750 \leq$ & $375 \leq$ & $375 \leq$ & $187.5 \leq$ & $375 \leq$ & $750 \leq$ \\
\hline $\begin{array}{l}\text { R. caucasicum } \\
\text { pollen }\end{array}$ & $375 \leq$ & $750 \leq$ & $375 \leq$ & $750 \leq$ & $750 \leq$ & $750 \leq$ & $375 \leq$ & $187.5 \leq$ & $187.5 \leq$ & $750 \leq$ \\
\hline Ampicillin & $11.687 \leq$ & $11.687 \leq$ & $11.687 \leq$ & $11.687 \leq$ & $11.687 \leq$ & $11.687 \leq$ & $11.687 \leq$ & N.D. & N.D. & $23.375 \leq$ \\
\hline Cephazolin & $11.687 \leq$ & $11.687 \leq$ & $11.687 \leq$ & $11.687 \leq$ & $11.687 \leq$ & $11.687 \leq$ & $11.687 \leq$ & N.D. & N.D. & $23.375 \leq$ \\
\hline Nystatin & N.D. & N.D. & N.D. & N.D. & N.D. & N.D. & N.D. & $23.375 \leq$ & $23.375 \leq$ & N.D. \\
\hline Solvent & - & - & - & - & - & - & - & & & - \\
\hline
\end{tabular}

N.D.: Not determined. Microorganisms: S.a., Staphylococcus aureus ATCC ${ }^{\circledR} 6538$ Gram (+); B.c., Bacillus cereus ATCC ${ }^{\circledR} 11778$ Gram (+); K.p., Klebsiella pneumoniae ATCC ${ }^{\circledR} 13883$ Gram (-); E.c., Escherichia coli ATCC ${ }^{\circ} 25922$ Gram (-); C.f., Citrobacter freundii ATCC ${ }^{\circledR} 43864$ Gram (-); L.m., Listeria monocytogenes ATCC ${ }^{\circledR} 7677$ Gram (+); E.f., Enterococcus feacalis ATCC ${ }^{\circledR} 29121$ Gram (+); C.a., Candida albicans ATCC ${ }^{\circledR} 10231$; S.c., Saccharomyces cerevisiae ATCC ${ }^{\circledast}$ 9763; P.a., Pseudomonas aeruginosa NRRL B-2679Gram (-).

could be classified as monofloral with $>45 \%$ of Rhododendron pollen being predominant for all samples (Sorkun, 2008). An examination of the SEM images of the three species showed that there was a slight difference between $R$. ponticum and $R$. caucasicum (Fig. 1). On the other hand, it was seen that the pollen obtained from $R$. luteum was clearly different from the other two.

The phenolic compounds contained in both honey and pollen obtained from the Rhododendron species were determined by HPLC (Tab. 2).

\section{Antimicrobial activity and MIC studies}

In this study, the crude samples of Rhododendron honey and pollen showed antibacterial and antifungal activity against the tested organisms (Tab. 3). A wide range of MIC values have been reported in studies which compare distinct honey samples tested against distinct species of bacteria. The MIC values obtained for the Rhododendron honey and pollen samples are 1500, 750, 375 and $187.5(\mu / \mathrm{mL})$ for the bacteria given in Tab. 4.

\section{Total phenolic contents and antioxidative} activities

Total phenolic contents, antioxidative activities based on DPPH and FRAP tests and inhibition potentials on linoleic acid peroxidation (LAP) of the samples are presented in Tab. 5.

\section{Anti-cholinesterase activity}

Although there have been several studies on the potential of acetylcholinesterase inhibition of such Rhododendron plant species as Rhododendron yedoense var. poukhanense bark, Rhododendron Iuteum Sweet, Rhododendron ponticum Linn. subsp. ponticum (Orhan et al., 2004; Mukherjee et al., 2007), there have been none on Rhododendron honey samples from this point of view. On the other hand, honey types other than Rhododendron species have been considered as a remedy for neurological diseases in the literature (Zaidi et al., 2019). Therefore, we investigated cholinest- 
Table 5.

Total phenolic content and antioxidative activity values of honey and pollen samples

\begin{tabular}{ccccc}
\hline Samples & $\begin{array}{c}\text { Total phenolic } \\
\text { content } \\
\text { (mg GAE/g } \\
\text { sample) }\end{array}$ & $\begin{array}{c}\text { DPPH } \\
\left(\mathrm{SC}_{50} ; \mathrm{mg} / \mathrm{mL}\right)\end{array}$ & $\begin{array}{c}\text { FRAP } \\
(\mathrm{mM} \text { TX/g } \\
\text { sample) }\end{array}$ & $\begin{array}{c}\text { Inhibition ratio (\%) on } \\
\text { LAP of the samples } \\
\text { at } 0.1 \mathrm{mg} / \mathrm{mL}\end{array}$ \\
\hline R. ponticum honey & $0.04 \pm 0.01$ & $64.002 \pm 2.49$ & $0.409 \pm 0.01$ & $14.695 \pm 1.25$ \\
R. luteum honey & $0.22 \pm 0.02$ & $35.634 \pm 1.95$ & $2.025 \pm 0.05$ & $8.550 \pm 0.05$ \\
R. caucasicum honey & $0.92 \pm 0.15$ & $16.652 \pm 0.80$ & $3.588 \pm 0.06$ & $12.563 \pm 0.70$ \\
R. ponticum pollen & $25.81 \pm 1.85$ & $1.054 \pm 0.85$ & $6.177 \pm 0.03$ & $9.368 \pm 1.03$ \\
R. luteum pollen & $13.63 \pm 0.77$ & $1.018 \pm 0.83$ & $2.676 \pm 0.25$ & $17.174 \pm 1.55$ \\
R. caucasicum pollen & $23.10 \pm 1.09$ & $0.496 \pm 0.01$ & $4.162 \pm 0.30$ & $37.158 \pm 2.25$ \\
\hline
\end{tabular}

Acetylcholinesterase and butrylcholinesterase inhibition potentials (\%) of the samples at $0.5 \mathrm{mg} / \mathrm{mL}$ concentration

\begin{tabular}{ccc}
\hline Samples & AChE & BuChE \\
\hline R. ponticum honey & $11.781 \pm 1.50$ & $0.099 \pm 0.02$ \\
R. luteum honey & $50.330 \pm 2.65$ & N.D. \\
R. caucasicum honey & $5.750 \pm 0.96$ & $0.790 \pm 0.35$ \\
R. ponticum pollen & $3.487 \pm 0.03$ & $18.855 \pm 2.55$ \\
R. luteum pollen & $8.671 \pm 0.85$ & $7.601 \pm 1.00$ \\
R. caucasicum pollen & $10.933 \pm 1.04$ & $4.343 \pm 0.55$ \\
Galantamine & $85.203 \pm 3.00$ & $24.778 \pm 3.25$ \\
\hline
\end{tabular}

N.D.: Not determined

erase inhibition potentials of honey and pollen samples and compared the results with galantamine, which is a standard cholinesterase inhibitor (Tab. 6).

\section{DNA damage inhibitory activities}

The protective effects of pollen and honey extracts on hydroxyl radical-mediated DNA damage have been investigated and given in Fig. 2 and Fig. 3, respectively.
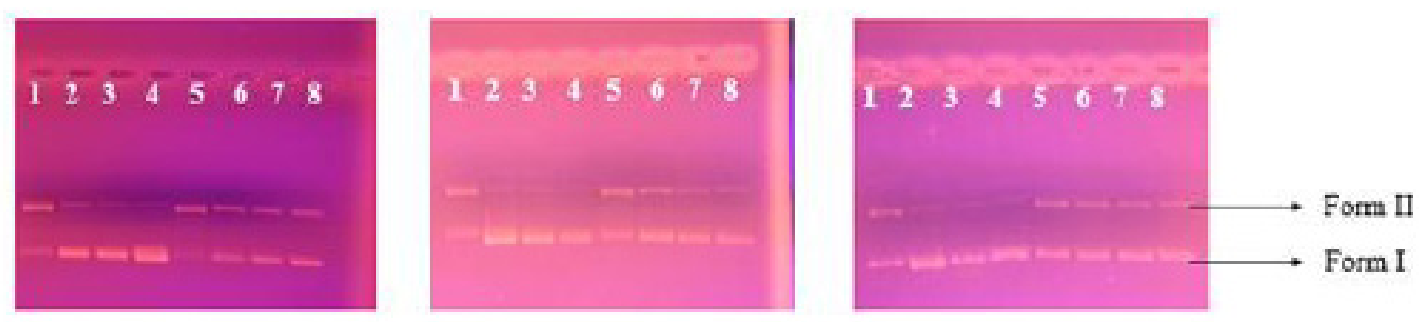

Fig. 2. Electrophoretograms of the interaction of pUC18 plasmid DNA with increasing concentrations of $R$. caucasicum polen, $R$. luteum polen, $R$. ponticum polen, respectively. Lane 1: $\mathrm{H}_{2} \mathrm{O}_{2}+$ pUC18 DNA; Lane 2: pUC18 DNA; Lane 3: THF+pUC18 DNA; Lane 4: TE+pUC18 DNA; Lane 5: $\mathrm{H}_{2} \mathrm{O}_{2}+\mathrm{pUC18}$ DNA+6.25 mg/ml extract; Lane 6: $\mathrm{H}_{2} \mathrm{O}_{2}+$ pUC18 DNA+12.5 mg/ml extract; Lane 7: $\mathrm{H}_{2} \mathrm{O}_{2}+$ pUC18 DNA+25 mg/ml extract; Lane 8: $\mathrm{H}_{2} \mathrm{O}_{2}+\mathrm{pUC18}+\mathrm{DNA}+50 \mathrm{mg} / \mathrm{mL}$ extract. 

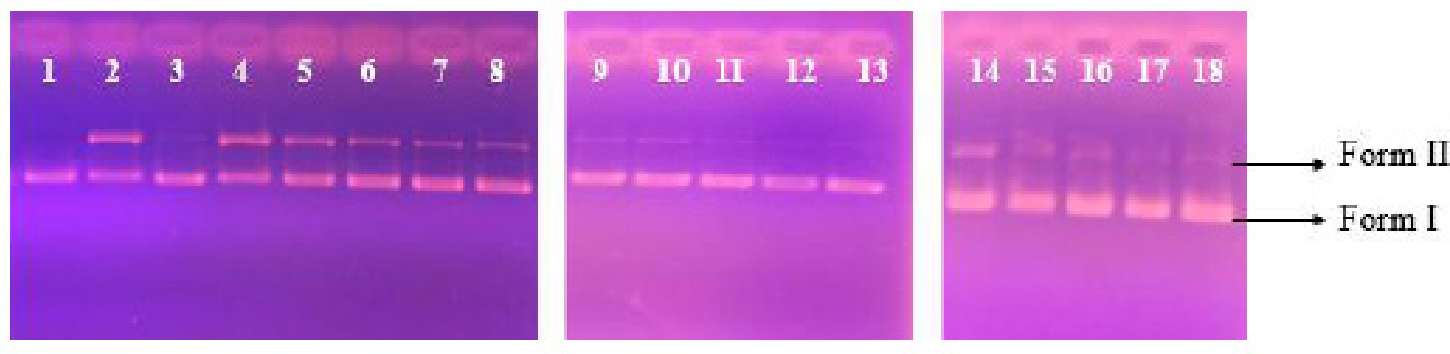

Fig. 3. Electrophoretograms of the interaction of pUC18 plasmid DNA with increasing concentrations of $R$. caucasicum honey, $R$. Iuteum honey, $R$. ponticum honey, respectively. Lane 1: pUC18 DNA; Lane $2: \mathrm{H}_{2} \mathrm{O}_{2}$ + pUC18 DNA; Lane 3: DMSO + pUC18 DNA; Lane 4,9,14: $\mathrm{H}_{2} \mathrm{O}_{2}+\mathrm{pUC18} \mathrm{DNA}+3.125 \mathrm{mg} / \mathrm{mL}$ extract. Lane 5,10,15: $\mathrm{H}_{2} \mathrm{O}_{2}+$ pUC18 DNA+6.25 mg/mL extract; Lane 6,11,16: $\mathrm{H}_{2} \mathrm{O}_{2}+$ pUC18 DNA+12.5 mg/mL extract; Lane 7,12,17: $\mathrm{H}_{2} \mathrm{O}_{2}+$ pUC18 DNA + 25 mg/mL extract; Lane 8, 13,18: $\mathrm{H}_{2} \mathrm{O}_{2}+$ pUC18 DNA+50 mg/mL extract.

\section{DISCUSSION}

The evaluation of physicochemical parameters of the honey and pollen samples points out that the samples are within the accepted limits of Turkish Food Codex except for the moisture for all three samples and the proline content of the honey obtained from $R$. ponticum.

According to the results obtained from the HPLC analysis, the cinnamic acid content is remarkable and is present in all honey and pollen samples. Myricetin was detected in all pollen samples, whereas p-coumaric acid, chyrisin, pinocembrin and phenylethyl caffeate were present in all honey samples. Other phenolic compounds syringic acid, ferulic acid, rutin, luteolin and hesperetin were also detected in one or more of the honey and pollen samples.

Medicinal plants and their crops in Turkey are often known by local people, but in the case of honey and pollen obtained from Rhododendron species, the toxic potential of these plants should be noticed (Öztaşan et al., 2005). According to the results obtained with the Rhododendron species in our study, it can be concluded that each honey and pollen crude extract exhibited more pronounced antibacterial and antifungal potencies in the bacteria and fungus. Therefore, it is reasonable to suggest that Rhododendron honey and pollen in small doses can be used for treating various diseases.

When we examine the total phenolic contents and antioxidative activities of the honey and pollen samples, it can be interpreted from Tab. 5 that $R$. ponticum honey revealed the lowest values for total phenolic content and DPPH and FRAP tests. This result is in agreement with the fact that the least proline content was determined for $R$. ponticum, because proline content can be used as a measure of antioxidant activity for edible plants (Karagözler et al., 2008). In the case of inhibition potential on lipid peroxidation, however, the honey sample from $R$. luteum exhibited the lowest inhibition ratio. In general, better antioxidant activity levels have been obtained for pollen samples rather than those of honey. Indeed, the pollen sample from $R$. caucasicum at a concentration of $0.1 \mathrm{mg} / \mathrm{mL}$ revealed a potential of $37.158 \%$ inhibition which is the maximum inhibition ratio obtained with the Rhododendron species tested in the current study.

As mentioned before, there have not been many studies in literature comparing honey and pollen samples from different Rhododendron species. Nevertheless, five different Turkish Rhododendron species collected from Artvin province have been analyzed for their volatile compounds where $R$. luteum flowers had the most diverse composition in comparison with those of $R$. ponticum, $R$. ungernii, $R$. sochadzeae and $R$. smirnovii (Tasdemir et al., 2003). On the other hand, Gül \& Pehlivan reported the phenolic content of monofloral Rhododendron honey from the Ordu district as $408.35 \mathrm{mg}$ GAE/100 g honey (Gül \& Pehlivan, 2018). It is worth noticing that, the phenolic content of the Rhododendron species collected in our study was higher. This can be explained because the phenolic content and antioxidant activities of honey samples 
may vary depending on the floral origin, geographical origin, humidity, temperature, climate and environmental conditions. However, in the present study, there is not a good correlation between antioxidant activity and the phenolic content. This behavior can be attributed to several other mechanisms that may result from different bindings and structures. Likewise, incompatibility between phenolic substance content and antioxidant activity has been explained with different radical scavenging activities of different types of polyphenols (Küçük et al., 2007). Silici, Sagdic, \& Ekici (2010) suggested that Rhododendron honey samples had different amounts of phenolic content with different degrees of antioxidant or antimicrobial activity. Therefore, comparison of our study with previous ones in literature may be evaluated as reasonable in the context of antioxidant activity.

Evaluation of lipid oxidation inhibition is another important parameter to evaluate biological antioxidant capacity (Watanabe, Nakajima, \& Konishi, 2008). Protocatechuic acid and protocatechuic acid methyl ester isolated from the leaves of Rhododendron simsii had been evaluated in terms of anti-lipid peroxidation activity and 1-10 $\mu \mathrm{g} / \mathrm{mL}$ of them expressed inhibition at $44.6 \%$ $100 \%$ ratio (Takahashi et al., 2001). Therefore, in addition to DPPH and FRAP tests, the inhibatory effect of investigated samples on induced lipid peroxidation was investigated as an indicator of antioxidant activity. With $0.1 \mathrm{mg} / \mathrm{mL}$ of pollen from $R$. caucasicum, an inhibition potential as high as $37.158 \%$ was achieved as seen in Tab. 5 . Recently, the inhibatory effect on the lipid peroxidation of honey samples, including Rhododendrons, has not been sufficiently investigated. Hence, the evaluation of the extracts prepared from honey and pollen samples from different Rhododendron species add privilege to this study.

We investigated cholinesterase inhibition potentials of honey and pollen samples and compared the results with galantamine. As can be seen from Tab. 6, the distribution of the results is quite interesting. Namely, AChE inhibition ratios of the honey samples were higher with respect to the pollen samples. On the other hand, BuChE inhibition degrees of the pollen samples were significantly higher; in particular, compared to galantamine, the pollen sample obtained from R.ponticum has a considerable amount of butrylcholinesterase activity. In addition, $0.5 \mathrm{mg} / \mathrm{mL}$ of honey extract prepared from $R$. luteum has $50 \%$ inhibition effect on AChE, which should be appreciated as a remarkable inhibition. As a comparison, thirty-one honey samples with different botanical origins were obtained from beekeepers in different regions of Algeria and investigated in terms of their acetylcholinesterase inhibition potentials (Zaidi et al., 2019). For most of them, the inhibition activity could not even be determined, while the $\mathrm{IC}_{50}$ values of the detected ones were between 0.367 and $0.629 \mathrm{mg} / \mathrm{mL}$. However, $1 \mathrm{mg} / \mathrm{mL}$ of the plant extract prepared directly from $R$. luteum and $R$. ponticum revealed inhibition potentials of $76.32 \%$ and $93.03 \%$ respectively (Orhan et al., 2004).

The interaction of pollen and honey extracts with DNA may depend on the binding and/ or cleavage properties, resulting in changes in three-dimensional DNA conformation. These changes have an impact on the DNA band density and in the rate of migration of DNA in an electric field (Asmafiliz et al., 2013). Plasmid DNA is found in supercoiled circular form I, singly nicked relaxed circular form II and linear form III. Untreated plasmid DNA migrates on the gel with two DNA bands (Akbaş et al., 2013). Interactions with the extract may cause conformational changes on the plasmid DNA and in DNA mobility through agarose gel. In the current study, pUC18 plasmid DNA was treated with $6.25,12.5,25$, and $50 \mathrm{mg} / \mathrm{mL}$ polen extract respectively (Fig. 2). Lanes 1, 2, 3 and 4 were run with pUC18 plasmid DNA untreated with pollen extract as a control, while lanes 5, 6, 7 and 8 pointed out plasmid DNA interacted with increasing concentrations of the extracts in the presence $\mathrm{H}_{2} \mathrm{O}_{2}$ condition. Pollen obtained from $R$. caucasicum, $R$. luteum, and $R$. ponticum appear to exhibit nearly similar effects against pUC18 plasmid DNA. Increasing doses of pollen extracts had a protective effect on hydroxyl 
radical-mediated plasmid DNA breaking.

In Fig. 3, lanes 1-3 were run with pUC18 plasmid DNA untreated with honey extract as a control, while lanes 4-18 pointed out plasmid DNA interacted with increasing concentrations of the extracts in the presence of $\mathrm{H}_{2} \mathrm{O}_{2}$ condition. Honey extracts obtained from $R$. caucasicum, $R$.luteum, and $R$. ponticum seem to exhibit nearly similar effects against pUC18 plasmid DNA. Similar to the case in pollen samples, increasing the doses of the extracts had a protective effect on hydroxyl radical-mediated plasmid DNA breaking. The highest activities obtained for the different honey samples were marked as $50 \mathrm{mg} / \mathrm{mL}$. On the other hand, $R$. ponticum honey had the most positive influence on damaged DNA.

As a result, antibacterial activity studies of monofloral honey samples from three different Rhododendron species revealed that each of the crude pollen and honey extracts exhibited pronounced antibacterial and antifungal potencies in the case of both gram-positive and gram-negative bacteria and fungus. Furthermore, MIC values have been determined for all samples, and in our study, inhibition potentials on acetyl- and butrylcholinesterase activity were evaluated for the first time for Rhododendron honey samples. Inhibition potentials of the extracts on 2,2'-azobis-(2-amidinopropane)-dihydrochloride (ABAP)-induced lipid peroxidation were also investigated as an indicator of antioxidant activity. Finally, the protective effects of pollen and honey extracts on hydroxyl radical-mediated DNA damage were investigated, and $R$. ponticum honey was observed to most positively influence damaged DNA.

\section{ACKNOWLEDGEMENT}

This work was supported by the Scientific Research Projects Coordination Department of Ordu University (ODUBAP) with grant number: B-1827.

\section{REFERENCES}

Akbaş, H., Okumuş, A., Kilıç, Z., Hökelek, T., Süzen, Y., Koc,, L., Açוk, L." Celik, Z. (2013). Phosphorusnitrogen compounds part 27. Syntheses, structural characterizations, antimicrobial and cytotoxic activities, and DNA interactions of new phosphazenes bearing secondary amino and pendant (4-fluorobenzyl)spiro groups. European Journal of Medicinal Chemistry, 70, 294-307. https:// doi.org/10.1016/j.ejmech.2013.09.046

Alan, S., Kürkçüoğlu, M., Göger, F., \& Başer, K. (2010). Morphological, chemical and indumentum characteristics of Rhododendron luteum sweet (Ericaceae). Pakistan Journal of Botany, 42(6), 37293737.

AOAC. (1990). Official methods of analysis of the AOAC, 15 $5^{\text {th }}$ ed. Method 958.09. Association of official analytical chemists. Arlington, VA, USA.

Asmafiliz, N., Klıç, Z,, Öztürk, A., Süzen, Y., Hökelek, T., Açוk, L.,... Üstündağ, Z. (2013). Phosphorus-nitrogen compounds: Part 25. Syntheses, spectroscopic, structural and electrochemical investigations, antimicrobial activities, and DNA interactions of ferrocenyldiaminocyclotriphosphazenes. Phosphorus, Sulfur and Silicon and the Related Elements, 188(12), 1723-1742. https://doi.org/10.10 80/10426507.2013.779273

Can, Z., \& Baltas, N. (2016). Bioactivity and Enzyme Inhibition Properties of Stevia rebaudiana. Current Enzyme Inhibition, 12(2), 188-194. https://doi.org/10 $.2174 / 1573408012666160402001925$

Chang, C., Yang, M., Wen, H., \& Chern, J. (2002). Estimation of total flavonoid content in propolis by two complementary colometric methods. Journal of Food and Drug Analysis, 103), 178-182.

Ellman, G., Courtney, K., Andres Jr, V., \& Featherstone, R., (1961). A new and rapid colorimetric determination of acetylocholin esterase activity. Biochemical pharmacology, 入2), 88-95.

Ertürk, Ö. (2006). Antibacterial and antifungal 
activity of ethanolic extracts from eleven spice plants. Biologia, 67(3), 275-278. https://doi. org/10.2478/s11756-006-0050-8

Gül, A., \& Pehlivan, T. (2018). Antioxidant activities of some monofloral honey types produced across Turkey. Saudi Journal of Biological Sciences, 25(6), 1056-1065. https://doi.org/10.1016/j. sjbs.2018.02.011

Karagözler, A., Erdağ, B., Emek, Y., \& Uygun, D. (2008). Antioxidant activity and proline content of leaf extracts from Dorystoechas hastata. Food Chemistry, 777(2), 400-407. https://doi.org/10.1016/j. foodchem.2008.03.089

Kurtoglu, A., Yavuz, R., \& Evrendilek, G. (2014). Characterisation and fate of grayanatoxins in mad honey produced from Rhododendron ponticum nectar. Food Chemistry, 167, 47-52. https://doi. org/10.1016/j.foodchem.2014.03.127

KüçüK, M., Kolaylı, S., Karaoğlu, Ş., Ulusoy, E., Baltaci, C., Candan, F. (2007). Biological activities and chemical composition of three honeys of different types from Anatolia. Food Chemistry, 100(2), 526-534. https:// doi.org/10.1016/j.foodchem.2005.10.010

Louveaux, J., Maurizio, A., \& Vorwohl, G. (1978). Methods of Melissopalynology. Bee World, 59(4), 139-157. https://doi.org/10.1080/000577 2x.1978.11097714

Manyi-Loh, C., Clarke, A., \& Ndip R. (2011). An overview of honey: Therapeutic properties and contribution in nutrition and human health. African Journal of Microbiology Research, 5(8), 844-852. https://doi. org/10.5897/ajmr10.008

Mukherjee, P." Kumar, V., Mal, M., \& Houghton, P. (2007). Acetylcholinesterase inhibitors from plants. Phytomedicine, 14(4), 289-300. https://doi. org/10.1016/j.phymed.2007.02.002

Orhan, I., Şener, B., Choudhary, M., \& Khalid, A. (2004). Acetylcholinesterase and butyrylcholinesterase inhibitory activity of some Turkish medicinal plants. Journal of Ethnopharmacology, 97(1), 57-60. https:// doi.org/10.1016/j.jep.2003.11.016

Oyaizu, M. (1986). Studies on products of browning reaction. Antioxidative activities of products of browning reaction prepared from glucosamine. The Japanese Journal of Nutrition and Dietetics, 44(6), 307-315. https://doi.org/10.5264/ eiyogakuzashi.44.307

Öztaşan, N., Altinkaynak, K., Akçay, F., Göçer, F., Dane, Ş. (2005). Effects of mad honey on blood glucose and lipid levels in rats with streptozocin-induced diabetes. Turkish Journal of Veterinary and Animal Sciences, 29(5), 1093-1096.

Palacios, I., Lozano, M., Moro, C., D’Arrigo, M., Rostagno, M., Martínez, J., ... Villares, A. (2011). Antioxidant properties of phenolic compounds occurring in edible mushrooms. Food Chemistry, 128(3), 674-678. https://doi.org/10.1016/j.foodchem.2011.03.085

Popescu, R., \& Kopp, B. (2013). The genus Rhododendron: An ethnopharmacological and toxicological review. Journal of Ethnopharmacology, 1471), 42-62. https://doi.org/10.1016/j. jep.2013.02.022

Sánchez-Moreno, C., A. Larrauri, J., \& Saura-Calixto, F. (1999). Free radical scavenging capacity and inhibition of lipid oxidation of wines, grape juices and related polyphenolic constituents. Food Research International, 32(6), 407-412. https://doi. org/10.1016/S0963-9969(99)00097-6

Silici, S., Sagdic, O., \& Ekici, L. (2010). Total phenolic content, antiradical, antioxidant and antimicrobial activities of Rhododendron honeys. Food Chemistry, 127(1), 238-243. https://doi.org/10.1016/j. foodchem.2009.11.078

Silici, S., Yonar, E., Sahin, H., Atayoğlu, A., Ozkok, D. (2014). Analysis of grayanatoxin in Rhododendron honey and effect on antioxidant parameters in rats. Journal of Ethnopharmacology, 156, 155-161. https:// doi.org/10.1016/j.jep.2014.08.027

Singleton, V., \& Rossi, J. (1965). Colorimetry of total phenolics with phosphomolybdic-phosphotungstic 


\section{_ AlKAN ET HL. _ _ Rhododendron honey and pollen samples}

acid reagent. American Journal of Enology and Viticulture, 16(3), 144-158.

Sorkun, K. (2008). Türkiye'nin nektarlı bitkileri, polenleri ve balları. Palme Yayıncillk.

Stevens, R. (1978). Rhododendron L. Flora of Turkey and the East Aegean Islands, Vol. 6.

Şenol, F., Orhan, I., Yilmaz, G., Çiçek, M., Şener, B. (2010). Acetylcholinesterase, butyrylcholinesterase, and tyrosinase inhibition studies and antioxidant activities of 33 Scutellaria L. taxa from Turkey. Food and Chemical Toxicology, 48(3), 781-788. https://doi. org/10.1016/j.fct.2009.12.004

Takahashi, H., Hirata, S., Minami, H., \& Fukuyama, Y. (2001). Triterpene and flavanone glycoside from Rhododendron simsii. Phytochemistry, 56(8), 875-879. https://doi.org/10.1016/S00319422(00)00493-3

Tasdemir, D., Demirci, B., Demirci, F., Dönmez, A., Baser, K., Rüedi, P. (2003). Analysis of the Volatile Components of Five Turkish Rhododendron Species by Headspace Solid-Phase Microextraction and GC-MS (HS-SPME-GC-MS). Zeitschrift Fur Naturforschung - Section C Journal of Biosciences, 58(11-12), 797-803. https://doi.org/10.1515/2nc2003-11-1208

Tasdemir, D., Brun, R., Perozzo, R., \& Dönmez, A. (2005). Evaluation of antiprotozoal and plasmodial enoyl-ACP reductase inhibition potential of Turkish medicinal plants. Phytotherapy Research, 19(2), 162166. https://doi.org/10.1002/ptr.1648
Turkish Food Codex (TFC), 2005. Number 26026, Food Codex-(No. 2005/49).

Usta, A., Yayli, B., Kahrinman, N., Karaoglu, S., Yayli, N. (2012). Composition and antimicrobial activity of essential oil from the flower of Rhododendron luteum Sweet. Asian Journal of Chemistry, 24(5), 1927-1930.

Watanabe, T., Nakajima, Y., \& Konishi, T. (2008). In vitro and in vivo anti-oxidant activity of hot water extract of Basidiomycetes- $X$, newly identified edible fungus. Biological and Pharmaceutical Bulletin, 37(1), 111-117. https://doi.org/10.1248/bpb.31.111

Zaidi, H., Ouchemoukh, S., Amessis-Ouchemoukh, N., Debbache, N., Pacheco, R., Serralheiro, M., Araujo, M. (2019). Biological properties of phenolic compound extracts in selected Algerian honeys-The inhibition of acetylcholinesterase and a-glucosidase activities. European Journal of Integrative Medicine, 25(September 2018), 77-84. https://doi. org/10.1016/j.eujim.2018.11.008 